Polgári Szemle, 15. évf. 1-3. szám, 2019, 193-203., DOI: 10.24307/psz.2019.0912

Máthé Gábor

\title{
A posztmodern jogállam
}

Post-Modern Rule of Law

\section{Összefoglalás}

Az írás a szerző és az érintett nemzetközi szakértők véleményének bemutatásával a 19. században születô klasszikus jogállam és a jelenkori posztmodern jogállam összevetésére vállalkozik. A tanulmány a nemzetállami szuverenitást, a tagállamok és az Unió központi szervei közötti jurisprudentiális problémák rendezését, a posztmodern jogállam anomáliáinak felszámolását, végső garanciaként a nemzetállamok alkotmánybíróságát és az Európai Unió Alkotmánybíróságainak Szövetségét helyezi középpontba.

Kulcsszavak: nemzetállami szuverenitás, posztmodern jogállam, nemzetállamok alkotmánybírósága, Európai Unió Alkotmánybíróságainak Szövetsége

\section{Summary}

In this paper the classical rule of law, born in the 19th century, is compare to the current post-modern rule of law through the opinion of the author and the international experts concerned. The paper focuses on nation state's sovereignty, the settlement of jurisprudential problems between the European Union and its Member States, the elimination of anomalies in the post-modern rule of law, as a final guarantee, the constitutional court of nation states and the Conference of European Constitutional Courts.

Keywords: nation state sovereignty, post-modern rule of state, the constitutional court of nation states, Conference of European Constitutional Courts

Prof. DR. MÁthé GÁbor CSc, az állam- és jogtudományok habilitált doktora, professor emeritus, ELTE Állam- és Jogtudományi Kar, NKE Államtudományi és Közigazgatási Kar (Mathe.Gabor@uni-nke.hu). 
Máthé Gábor: A posztmodern jogállam

\section{A KLASSZIKUS JOGÁllam A 19. SZÁZADBAN}

Az elmúlt kétszáz esztendố elsô felének kiegyensúlyozottsága a Szent Szövetség három alapítójának, I. Sándor orosz cárnak, I. Ferenc osztrák császár és magyar királynak, valamint III. Frigyes Vilmos porosz királynak a katonai szövetségén, az általuk deklarált területrendezési és együttmúködési elveken nyugodott. Európa történetében a nagyhatalmi kezdeményezéseket nevezetes kongresszusok kísérték, közülük is kiemelkedó a 19. századi bécsi kongresszus, amely 1914-ig eredményesen kezelte a nemzetközi válságokat (Harmat, 2015). Három követelmény együttes érvényesítése volt a záloga a kontinens eredményességének. A legitimitás, azaz a hatalomgyakorlás örökletes, avagy választás útjáni rendje, majd az egyensúlyban lévó államok szövetsége volt a kritérium, s végül a konfliktusok feloldásában mindig a jövố iránti felelôsség dominált. A kongresszust követố elsố száz évben új rend alakult ki. A francia forradalom eszméivel szemben hirdették meg a legitimitást, s ebben a forradalommal szembeni restaurációban fơként a monarchikus, dinasztikus szolidaritás fejeződött ki. Továbbá ez a hatalom keresztény volt: a trón és az oltár szövetségében épült ki, s végül meg tudott maradni kontinentálisnak (Máthé, 2015a).

Az 1860-as évekre azonban a megváltozott érdekviszonyok felismerésével a szövetség fokozatosan kezdte befogadni az alapvetôen új szemléletet követelô hatalompolitikai elveket, s mindenekelôtt a jogállami intézményrendszer megteremtésének szükségességét ismerte fel.

A jogállam két attribútuma a szabadság és a tulajdon szentsége: az állam-társadalom-egyén triászát tekintve pedig lényeges követelmény, hogy a hatalom gyakorlására ellenőrzô intézmények jönnek létre. A korai jogállam fogalom a politikai liberalizmus kívánságainak összegzése: az uralkodó alárendelése a pozitív jognak, az állami tevékenység joghoz kötése, illetve hogy a jogalkotás és végrehajtás formális lehetôségeit ne használják fel a polgárok alapvetô jogaiba történô jogellenes beavatkozásra.

A kialakuló új államban kompromisszum született a formális állam javára. A bécsi Ogris professzor szerint a jogállam jellegével a törvényes rend sérthetetlensége adott, nem pedig a tartalma. Az állam lényege, hogy a jog által pontosan határozza meg és megváltoztathatatlanul biztosítsa saját múködésének pályáját, határait, valamint polgárainak szabad mozgásterét. Az erkölcsi eszméket államként, vagyis közvetlenül ne valósítsa meg messzebbmenóen, mint ahogy az a joghoz tartozik, fogalmaz. Világossá vált, hogy a biztos jogalapok, a jogvédelem, a bírák egyéni mozgásterének megôrzése stabilizáló, gazdaságilag eloonyösen ható tényezô. A politikum érdeklődése így egyfelôl az elérendô eredményekre összpontosult, másrészt a formális jogvédelem különösen a közigazgatási ügyek területén vált központi kérdéssé. Mindez Werner Ogris szellemes megfogalmazásával: A jogállam eszméje eltávolodott az államelmélettôl, s nagy vehemenciával átugrott a közigazgatási jogra és a közigazgatás-tudományra (Ogris, 2010:23). A döntô kérdést ugyanis az jelentette, hogy a biztosított jogok mennyire érvényesülnek a gyakorlatban. Erre született a közigazgatás ellenórzésének kényszere, mely igen kifejezô Otto Mayer véleményében, miszerint a jogállam a jól szervezett közigazgatási jog állama. Így 1896-ban nálunk is létrejött a jogvédelem kiemelt intéz- 
ménye, a Közigazgatási Bíróság, mellyel konkrét formát öltött a polgárok védelme az állam jogellenes intézkedéseivel szemben. Ehhez járultak további sarokpontként a hatalommegosztás, a bírák függetlensége és a katalógusba foglalt, mára már többgenerációs alapjogok rendszere. A klasszikus hatalmi triász intézményrendszerének joghoz kötöttségét pedig a nagy jogalkotások szolgálták: a kereskedelmi törvényünk mellett a magánjogi kodifikáció kiemelkedô teljesítményét jelentô javaslatok, a polgári perrendtartás, s nemkülönben a büntetôjogi dogmatika remekeként az alkotójáról elnevezett büntetô törvénykönyv, a Csemegi-kódex, amely tényállásaiban több jogásznemzedéket is kiszolgált.

A 19. század Kelet-Közép-Európájában létrejött kettôs Monarchia, Ausztria-Magyarország két önálló államként, ám közös ügyekkel és erre vonatkoztatott közös szervekkel, mint a szent szövetségbeli elveket realizáló, rendkívüli területi változatosságú, sokkultúrájú entitás, sikeresen építette ki a hatalommegosztásos intézményrendszer teljes spektrumát (Sári, 1995), s megalkotta az európai jogi értékeket hordozó kódexeket (Máthé, 2015b). A Monarchia jellemzésénél fontos kiemelni azt a tényt, hogy elsóként a jogrend volt a domináns, s e keretek között bontakozott ki a gazdaság. Az 1870 és 1914 közötti helyi piacok dominanciájával múködő gazdaság, alapvetôen szociális indíttatásával, új polgári életstílust eredményezett. Figyelemre méltó példázat lehet a kettôs Monarchia gazdasága, ahol a pragmatikus ügyek költségvetési aránya 70:30 százalékos volt, s néhány módosulás után, utoljára 1908-ban 63,6:36,4 százalékos arányban alakult, a birodalmi tanács országainak hátrányára (Balogh, 2007). A gazdasági eredményesség pedig ebból következôen a magyar szuverénnek kedvezett. Eisenmann francia történész értékelése szerint Magyarország 1867-tel a költségek harmadáért megkapta a jogok felét, és megszerezte a befolyás kétharmadát a Monarchiában (Eisenmann, 1904).

Fredric Jameson, az Egyesült Államok egyik jelentős kortárs gondolkodója a posztmodern kulturális logikájával rendkívül kifejezô értékelését adta a Monarchiának. Ez azért is fontos, mert mai korunk csak a saját lehetôségeinek feltételeirôl gyárt elméleteket, amelyek csupán a változások, átalakulások puszta felsorolásából állnak. Jameson pedig úgy próbál változtatni, hogy megkísérel történelmileg gondolni a jelenre, olyan korban, amely már elfelejtette, hogyan is kell a történetiséget használva érteni a jelent. „A Monarchia nemcsak az utolsó archaikus birodalom volt, de egyben az elsó multinacionális, többetnikumú állam is, amely Poroszországgal összehasonlítva kényelmesen impotens, a cárokhoz képest pedig emberséges és toleráns, s végsố soron nem olyan rossz kombináció ez a saját nemzetek utáni, de nacionalizmusok által még mindig marcangolt korunkban is érdekfeszító modell” (Jameson, 2010:292).

\section{A POSZTMODERN JOGÁlLAM KORUNKBAN}

A jogállami alapelvek realizálásának folyamata sem a kiépülés idején, sem a jelenkorban nem zökkenómentes. Fontos, hogy a jogállami modell egyáltalán nem lezárt rendszer, állandó fejlesztésre szorul. Nincs garancia arra, hogy az eredményei örök idôkre megmaradnak. Jó példa erre a 21. századi Európai Unió. A tagállamok ugyanis 
a saját és a közös politikai intézményrendszer kettôsségének szorításában vergódnek, jellemezte a helyzetet az Európai Parlament volt elnökeként Martin Schulz, mondván, Európában a nemzeti szuverenitás a hatalmi ágak elválasztásán alapul: van egy kormányunk, amelyet a parlament leszavazhat, és egy független bírói kar, amely órködik azon, hogy a törvényeket betartsák.

A 20. század elején, az elsố világháborút lezáró versailles-i béke felrúgta a területi rendet, szétzilálta Közép-Európát. A második világháború utáni jaltai egyezménnyel, majd a párizsi békemegállapodással pedig Európa megindult a transzatlantivá válás útján, lassan elveszítve világpolitikai befolyását. Az 1989. december 2-i máltai egyezmény pedig Kelet-Közép-Európa újraintegrálásával már teljesen új minőséget hordozott, hiszen az USA által közvetített washingtoni konszenzus szellemében kellett ezeknek a területeknek visszatérnie a 20. századi római szerzôdések politikai és gazdasági kapcsolatrendszeréhez.

Az egypólusúvá vált világban Kelet-Közép-Európa integrálása még inkább eltávolodott a korábban elfogadott elvektôl. A washingtoni konszenzus elemeinek sorrendje privatizáció, dereguláció, kereskedelmi liberalizáció - a nemzetközi pénzvilág forgatókönyve alapján realizálódott. A programalkotóknak ugyanis nem sikerült az államiság különböző dimenzióit konceptuálisan elkülöníteni, és megérteni, hogy azok miként kapcsolódnak a gazdasági fejlódéshez. A privatizáció hatalmas aszimmetriákat szült, amelyek korrigálása az állam feladata lett volna. Találóan jegyezte meg Milton Friedman, a szabadpiaci közgazdaságtan legkiválóbb képviselôje, hogy bebizonyosodott a tétel: a jogrend valószínúleg alapvetôbb a privatizációnál (Gecsényi-Máthé, 2009:16-18).

E nemzetközi folyamatok összefüggéseirôl továbbá, rendkívül tanulságos értékelést közöl kiváló tanulmányában Dr. Kádár Béla akadémikus közgazdászprofesszor. A tényhelyzet világos rögzítése ugyanis önmagáért beszél: „A 20. század két önpusztító világháborúja (európai polgárháborúja) nyomán alakult ki az a fél évszázados nemzetközi erôtér, amelyben Európa sorsát Európán kívüliek alakították, Jaltában a szovjet, Máltán 1989 decemberében az amerikai érdekeknek megfelelôen. A rendszerváltás feltételeit, feladatait kívülrôl határozták meg. Ez alapvetô mozgástér-alakító tényezô volt, ám... e koncepcionális meghatározottságból a közép-európai országok felzárkóztatása, pénzügyi támogatása nem volt stratégiai cél” (Kádár, 2018).

Noha a kilencvenes években a volt szocialista országok gazdasági átalakulásában „az IMF kapott vezérlópult mozgástér átalakító szerepet... az IMF azonban a washingtoni konszenzus tartalmát tekintette stratégiának" - hangsúlyozza a magyar közgazdaságtudomány doyenje, akinek szakmai álláspontja vitathatatlan, azaz: „külsố pénzügyi támogatás hiányában az IMF-terápia eleve koncepcionális jellegú gazdaságpolitikai mozgáskorlát volt" (Kádár, 2018).

Jameson a monográfiájában igen meggyốzôen fest kórképet a posztmodern mai elméletéról: „Eltúnôdhetünk, hogy korunk ideológiája nem vált-e az árucikk saját ideológiájává, vajon a gyakorlat nem vette-e át az eltökélt állásfoglalás és egy politikai vélemény teljes mellszélességgel való támogatásának helyét. A média itt találkozik ugyanis a piaccal, és ketten együtt táncolnak egy régebbi típusú intellektuális kultúra sírján” (Jameson, 2010:407). Ugyancsak drámaian igaz az az értékelés, mely szerint 
a „nemzetállam megszúnt fontos formális szerepet játszani egy folyamatban, amelyet a tôke alapvetô megváltozásával teljesen meghaladott, s a korábbi termelési módból visszamaradt csökevényként élteti tovább" (Jameson, 2010:422).

A közgazdasági irodalomban határozottá vált nézet szerint a legjelentôsebb nemzetközi fejlôdési szakadékot a fejlett Észak és a világnépesség nagyobb részét magában foglaló, gyengén fejlett Dél közötti kompromisszumos együttmúködés lehetetlenülése jelenti. A globalizálódó világban további törvényszerúségként hatnak az aszimmetrikus interdependenciák a tôkét exportáló és a tôkét befogadó országok között. A hazai gazdaság feletti nemzeti szuverenitás leszúkülése, azaz a gazdaság jövôbeni struktúráját meghatározó döntések idegen kézbe kerülése a transznacionális társaságok térhódításához vezet, amelyek az áru-, tôke- és technikai transzferjeik, stratégiai együttmúködéseik révén globális üzletpolitikát folytatnak. Ez a globalizáció káros hatású, mivel a nemzeti szuverenitást, pontosabban az állami szuverenitást erodálja - a piaci túlsúly állami kiegyenlítését gyengíti -, és a döntéshozatalnak határokon kívül helyezését szorgalmazza. A globalizáció tehát újradefiniálja a nemzetállam mint a nemzetgazdaság hatékony menedzserének szerepét (Szentes, 2002).

Szükséges belátni azt is, hogy a globalizálódás korában a kormányzatok felelôssége és az állam szerepe nem csökken. Nagymértékben a kormányzati politikától függ, mennyire sikerül a világgazdasági és integrációs folyamatokban, valamint a transznacionális társaságokkal való együttmúködésben minél kisebb költséggel, kockázat nélkül minél több hasznot megszerezni. Ám a nemzetgazdaságoknak mégis arra kell törekednie, hogy a nemzeti előrehaladás folyamatában az egymást elôsegítô, kölcsönösen támogató hatások domináljanak.

\section{A TÉRSZERKEZET VÁLTOZÁSÁNAK KÖVETKEZMÉNYEI}

A 20. század kilencvenes éveiben a társadalomtudományban új fogalom keletkezett, a szupraterritoriális tér, amely új jelenségként azt jelezte, hogy az államok hagyományos területi szerkezetével szemben valami új alakult ki. A gazdaság és jog kapcsolatát a korabeli nemzetközi jog szerzôdési rendszere uralta, de illeszkedett a klasszikus térszerkezethez, állapítja meg a diplomáciatörténet szakértője, Hargitai József. A modern nemzetközi jog az elsố világháború után nem jelentette a jog hagyományos térszerkezetének változását, sốt a nemzetközi jog belsô fejlődése, ha úgy tetszik, nemzetközivé válása, az európai kultúrkörön kívüli kiterjedése sem érintette a térszerkezet változását (Hargitai, 2004).

Ha egy állam nincs egy másik állam jogi uralmának alávetve, akkor szuverén. A nemzetközi jog azonban nem ismeri a szuverenitás fenntartásának kötelezettségét, tehát egy állam a szuverenitásáról vagy annak egy részéról le is mondhat azzal, hogy csatlakozik egy államszövetséghez. „Ebból argumento a maiore ad minus az következik, hogy a szuverenitás részelemeirôl is lemondhat, amely folyamat tulajdonképpen minden szerzôdés megkötésével megtörténik egészen addig, amíg ez a szuverenitásfogalom, mint például az EU-hoz történố csatlakozással, majdnem üressé válik" (Hargitai, 2004). 
A 21. század elejére kialakuló kép úgy foglalható össze, hogy a nemzetközi jog és az abban megjelenó egyetemes szerzôdések rendszerében az állam olyan kötelezettségek hálózatába bonyolódott, ahol a nemzetközi jog értéksemleges állapota felborult. Nem véletlenül nyert teret újkori tételként: a jog alternatív, nem törvényi forrásból is fakadhat. Ez a jog a világpiaci struktúrát fogja át, messzemenóen függetleníti magát a nemzetállami vagy nemzetközi jogalkotásoktól (Hargitai, 2008). Az új világrend, a posztmodern világ támogatói aktívan serkentik e folyamatokat, s mialatt az államok politikai, jogi és gazdasági téren elveszítik korábbi hatalmukat, ezzel párhuzamosan növekszik más aktorok befolyása, amelyek az állammal szemben paralel tevékenykednek. Igen nagy befolyásra tesznek szert továbbá a multinacionális cégek, civil szervezetek és kezdeményezések, NGO-k, s az új világrend globálisan érvényesülố normáival egy sajátos „földindulást” generálnak. Az ún. transznacionális jog alkalmazásával példaként a multik határon átlépó szervezeti struktúrái emelendók ki, nem is említve a „világ egy globális szerelôszalag” szindrómát, ahol az árumozgás nem a nemzetállami export-import, hanem e nemzetközi cégek fiók- és leányvállalatai közötti árumozgás színtereként múködnek. Sajátosan alakul továbbá, hogy csak azoknak a normáknak engedelmeskednek, amelyek a konszernen belüli nyereség maximalizálására irányulnak. Emellett jellemzó, hogy nem a befektetés helye szerinti ország jogrendje szerint múködnek. Ennek az elkülönüló önállósodásnak egyértelmú magyarázatát adhatja az a tény, hogy e cégek bevétele a nemzetállami költségvetések többszörösét teszi ki.

A 20. század kifogyhatatlan a „térváltozások” módozataiban. Így példaként az éter tér a múlt század második felében még regionális jogként szerepelt, mára azonban a nagy multinacionális távközlési cégek már más törvények alatt múködnek. Ennek a tradicionális térnek a globalizált változata mint virtuális tér (internet) szerepel. Az internet ugyanis szétrombolta a jogi térszerkezeti formákat. A kibertér vagy virtuális tér nem más, mint az emberek és gépek közötti kommunikáció hálójában létrehozott tranzakciók, kapcsolatok és gondolatok halmaza. Kiderült, hogy a világháló egyben gazdasági cselekvések színtere is, jelképes piacként funkcionál, ahol valóságos áru- és tôkemozgás zajlik. Ámde az internetet felfedezte az állam is, a közigazgatás korszerúsítésénél kívánja mind szélesebb körben igénybe venni. Az informatika elterjedése továbbá különös hatással is járt, létrejött egy olyan szakmai elit, amely egyre tudatosabban lép fel az állam korlátozó szabályozásával szemben. Ez a team fơként az emberi jogok követelményeire hivatkozva technikai, programismeretei birtokában képes felülírni a jogi szabályozás által lefedett területeket.

A posztmodern jogállam vázlatszerú jellemzőinek bemutatását egy igen érdekes sajátosság felelevenítésével zárjuk. Elgondolkodtató, hogy a nemzetállami igazságszolgáltatás hagyományos formái nem bizonyultak alkalmasnak az érdemi érvényesítésre a transznacionális formációk jogi ügyeiben. Nem véletlen tehát a nemzetközi választottbíróságok szerepének növekedése. Szembeötlő ugyanakkor, hogy a hatalmon szervezôerôvel rendelkezố multinacionális birodalmak célkitúzései között az állam „valamiféle" megszüntetése még nem szerepel. Pillanatnyilag ugyanis elegendőnek túnik, hogy az állam szerepét a maguk érdekeinek megfelelóen megváltoztatják, elvégre a választottbírósági ítéleteket valakinek végre is kell hajtania. 
A fentiek összegzéseként megállapítható, hogy a hagyományos nemzetállami alkotmányok alapján szabályozott törvényalkotási folyamatok és struktúrák (jogforrási hierarchia, jogrendszer) lassan széttöredeznek. Ebból következik Preuss (1999) lényegre törố és nagyon kifejezô tanulmányának összegzô mondata: Megvalósult az állami törvényhozók hatalomfosztása. Nos, az állami törvényhozók „hatalomfosztása” lényegében az EGK folyamatos bóvülésével létrejött Európai Unióval tetôzött. Az EU a tagállamok szuverenitása egyes elemeinek átruházásával és az európai értékekre alapozottan jött létre. Pedig a szuverenitás az európai civilizáció legnagyobb találmánya, és az egyetlen olyan keret, amin belül egy életképes demokrácia múködhet, állítja aforisztikus bölcsességgel Thierry Baudet. Itt és most nem foglalkozhatunk az államok közötti „hatalomgyakorlás” elvi kérdéseivel, ám azt mindenképpen hangsúlyozzuk, hogy a szuverenitás és a jogállam komplementer fogalmak (Máthé, 2014).

\section{VisSZATÉRÉS A JOG POZITIVIZÁlódÁSÁHOZ?}

Helmut Coing professzor monográfiájában kiemelten foglalkozik az általános jogpozitivizmussal. Megállapítja, hogy „...korunk joga egy olyan evolúció terméke, amely az archaikus társadalmi rendszerektôl az ókori magaskultúrákig, s végül társadalmi formáink újkori magaskultúrájáig zajlott le. Ez az evolúció elsôsorban a mind nagyobbá váló komplexitás uralásában jelentkezik. Bár a jognak egyrészt biztonságot kell nyújtania a fennálló normatív elvárások számára, másrészt azonban teret kell hagynia újabb elvárásstruktúrák fejlődésének és ezzel újabb normatív rendszerek kialakulásának" (Coing, 1996:87-88). A normatív és kognitív tételezések párhuzamáról vélekedve a jelenlegi jogfilozófiai viták apropóján külön is kitér Luhmann (1981) elméletének bírálatára. Luhmann koncepciójának lényege ugyanis, hogy a pozitív jog döntések révén jön létre és érvényesül, de legitimációjában már nincs szerepe egy statikus világrendnek, ahogy azt a klasszikus természetjog európai tradíciója megalapozta (Strauss, 1999). A pozitív jogot különösen megalkotásának rendje kell hogy legitimálja, az a politikai folyamat, amely során a kiválasztásra vonatkozó döntések megszületnek. A klasszikus természetjog egy örök világrend visszatükrözôdése volt, és a klasszikus igazságosság eszme feltételezett egy átfogó tökéletes rendet, ami legitimálni tudta a jogot, és kritériumokat szolgáltatott a jogos és jogtalan megállapításához a jogi döntések meghozatala során. Az azonban mára világossá vált, hogy a modern komplex társadalom feltételei között erre nincs mód. Ezért ennek pótlására, „a jogrendszer adekvát komplexitásának” biztosítására egy „rendszerelméleti interpretációnak” kell lépnie (Coing, 1996).

A 21. század posztmodern világában, éppen a fentiek okán is, még inkább nélkülözhetetlen a jogállam követelményéhez ragaszkodás. Vitathatatlan meghatározó érték a jogállam, amelynek vezérgondolata a jogbiztonság, amelyben a jog az állam múködésének mérôfaktora. A mai jogállam tehát: alkotmányos állam, amely szabályozza a törvényhozás menetét; törvényi állam, amely szabályozza az egyén viselkedését, állami szerveket állít fel, amelyek felépítését és kompetenciáját meghatározza; és jogvédô állam, amely az alkotmány és a törvények betartását megfelelô intézmények segítségé- 
vel biztosítja. Jellemzői továbbá: a törvényhozó alkotmányhoz kötése; a bírói hatalom törvényhez kötése; az alapjogok védelme; az állami szervek felelóssége a jogszabályok betartásáért; a jogi rendelkezések megfogalmazása és kihirdetésének egyértelmúsége.

Jordan Peterson kanadai professzor 2018-ban megjelent monográfiájában szellemesen fogalmaz korunkról: „Az órült és felfoghatatlan posztmodern makacskodás motivációja, hogy a társadalmat át kell alakítani, avagy el kell törölni az elfogultságot, amíg el nem érjük a méltányosságot. Ez a tézis figyelmen kívül hagyja azt a tényt, hogy nem lehet egyidejúleg mindkét állítás igaz, ahogy egy másik állítással sem lehet megmagyarázni, hogy maga a logika és a tudományos módszerek is csak egy sajátos patriarchális rendszer részei” (Peterson, 2018:348). Tehát az embereknek szükségük van elvekre, különben felüti a fejét a káosz. Szabályok, mértékek és értékek kellenek. „Meg kell határoznunk, hová tartunk, hogy alkudozhassunk önmagunkról, s mindezt ne gyúlölködve tegyük. Ne becsüljük alá az elôrelátás és az iránymutatás erejét. Határozzuk meg, hogy kik vagyunk" (Peterson, 2018:98). Ez az intelem is egyértelmúvé tette, hogy vissza kell térnünk a természetjogi kiindulóponthoz, a jog pozitivizálódásához.

Minden történeti alkotás ugyanis egyedi formában létezik. A jog a kultúra egészének része, tárgyhoz kötött, és elsôsorban a társadalmi rendben felmerült problémák megoldását jelenti. Tagadhatatlan, hogy a gazdasági hatalom és minden hatalom szerepet játszik (avagy próbál játszani) a jogképződésben. De a kultúra „szálai” is erósek, és nem tûrnek egyoldalú rendezést (Coing, 1996:163-164). Mindezek okán a jogtudománynak és múvelőinek a közeljövôben kiemelkedô szereplőnek kell lennie az EU feszítô problémáinak megoldásában. A jogtudomány szellemtudomány. Egyrészt a jogrendszer gyakorlati megvalósulásának szolgálatában áll, másrészt a hatályos berendezkedések tudománya. Edmund Burke magasztos értékelésével: „A jogtudomány az emberi értelem büszkesége, amely minden hiányossága, terjengôssége és hibája ellenére sem más, mint a különböző korok összegyújtött bölcsessége, amely összeegyezteti az eredendố igazságosság elveit az emberi érdekek határtalan sokszínúségével (Coing, 1996:273).

A jogtudományi polémiák, nézetkonfrontációk jelen korunknak is sajátosságai. Példaként emeljük ki a szuverenitásról szóló viták közül Jeremy Rabkin (2004) amerikai kutató koncepcióját, aki amellett érvel, hogy a globális rendnek is az államok szuverenitásán kell alapulnia (Máthé, 2013:160-161). Ezek ugyanis azok az egyedülálló nemzetközi tényezők, amelyek egyesítik a demokratikus legitimációt a jogszabály kikényszerítési képességével. Nem is említve, hogy például az EU-relációban az egyes szuverének között, egybehangzó akaratelhatározás alapján, létrehozhatók gazdasági régiók, régióközpontok a határokon belüli és határon túli kölcsönösségi területeken.

Az említettek lehetnek tehát a 21. századi államelméleti prioritások, amelyek mentén a közös valuta jegyében fogant és a magállamok által múködtetni kívánt Európai Unió egész szervezetét, döntéshozatali mechanizmusát újra kell alakítani, mégpedig nem a globalizációhoz, hanem Fernand Braudel (2008) találó megfogalmazásában, egyszerre több gazdasági világhoz igazodva. Európán belül pedig kialakíthatók a közös értékhordozó régiók. A történeti régiók sajátosságai ugyanis egybeesnek az EU jelenkori gazdasági trendjeivel (Szúcs, 1983). 


\section{Az ALKOTMÁNYBÍRÓSÁG VÁLTOZÓ SZEREPKÖRBEN}

Az európai jogrendszer összehasonlítása elôtt álló sajátos kihívások jogi és politikai téren hatalmas jelentôségúek, írja a heidelbergi Max Planck Institut igazgatója, Armin von Bogdándy a kiemelkedô színvonalú Handbuch Ius Publicum Europaeum hatodik, az alkotmánybíráskodásról írt kötetének bevezetôjében. Ennek a megkülönböztetett figyelemnek többek közt az az oka, hogy az Európai Unió közjogában egyedülálló módon összekapcsolódik az Unió elsôdleges joga, az Emberi jogok európai egyezménye és az állami jogrendek. Az európai közjog ezt összeegyezteti különbözô, önmagát alkotmányjogi normativitásként értelmezô rendszerekkel anélkül, hogy egyetlen jogrendszerré összeolvasztaná. A kötet szerzôi pedig az alkotmánybíróságok szerepének, gyakorlatának analízisével, az ebból levonható tanulságokkal egyértelmúsíti, hogy ez az intézmény lehet a végsố garancia a posztmodern jogállam anomáliáinak felszámolására (Bogdandy-Grabenwarter-Huber, 2016:VII.).

Az európai jogrendszer alapja az uniós tagállami jogrendszerek által definiált azon terület, amelyen a tagállami és az uniós normák egyaránt érvényesülnek. Igaz tehát Bogdándy professzor tétele, hogy egy komplex jogrend, amelynek nincs kifinomult dogmatikája, rendszerint híján van a világosságnak, az elooreláthatóságnak és a tisztességnek (Máthé, 2017). Amikor pedig területrôl beszélnek az EU-szerzôdés megalkotói, akkor a teljes pozitív jog értelmezési lehetôségét értik alatta.

Megállapítható, hogy az alkotmánybíráskodás az európai jogrendszeren belüli öszszehasonlítás elméleti bázisa, s ez a szerepkör alapozza meg az alkotmánybíróságok szövetségének intézményét. Az alkotmánybíróság mai gyakorlata nem egy világosan lehatárolt jogterület értelmezése, sokkal inkább egy ún. „beépített”, az összefüggésekre kiemelt figyelmet fordító jogalkotási folyamat. Ennek folytán Bogdandy és szerzôtársai öt speciális funkciót különböztetnek meg a szövetségben múködô alkotmánybíróságok körében: összekötô, illetve megvalósító; fordító; legitimációs; jogvédelmi hézagok zárására irányuló; az uniós jog és az alkotmányjog találkozására vonatkozó kontrollfunkciót tételeznek. Ezek közül kiemelkedô a jogvédelmi hézagot kitöltô szerepkör, különösen az identitáskontroll és az ultra vires kontroll formájában játszott szerep, hogy védelmet nyújtsanak az európai szervek kompetenciatúllépésével szemben. E kontrollnak döntő jelentôséget az ad, hogy elmélyíti és racionalizálja a közös európai megoldások kidolgozását. Az Alkotmánybíróságok Szövetsége azzal is nagyban hozzájárul az európai jogrendszer fejlôdéséhez, hogy a nemzeti bíróságokkal horizontális együttmúködésben kontrollfunkciót lát el az Európai Bíróság és az Emberi Jogi Bíróság tevékenysége fölött. A jelenkori jurisprudenciális problematika megoldásában ezért jövôbe mutató axiomaként értékelhetô: az európai jogi kultúra és az európai közjog nem nôhet ki csupán az uniós jogból és az Emberi Jogi Bizottság ítélkezési gyakorlatából. Ehhez sokkal inkább az igazságszolgáltatással megbízott nemzeti szervek hálózatba kapcsolására van szükség (Bogdandy-Grabenwarter-Huber, 2016:8-10).

A kötet szerzôi elutasítják az európai államok alkotmánybírósági egységes modelljének koncepcióját, az esetleges erre való törekvést, és az EU-szerzôdés szöveganalízisével igazolják, hogy ha a tagállami alkotmányrendszerek egyenértékúek, akkor eb- 
ből következik a „sokszínú mechanizmusok” elismerése, amelyek védik az alkotmány normativitását (Bogdandy-Grabenwarter-Huber, 2016:13-16) Korrekt az Európai Alkotmánybíróságok Konferenciájának alapszabályára hivatkozás, mely szerint a bíróság hatáskörét különösen a normakontroll, a bírói függetlenség s a demokratikus jogállam alapelvei melletti elkötelezettség, valamint az emberi jogok védelme jelenti (Bogdandy-Grabenwarter-Huber, 2016:16-17). E sui generis alakulat jövőjét illetően pedig a jogtudományi dogmatikai argumentáció minôségére mint kötelezô példázatra utalnak a kiváló szakemberek. Megállapítják, hogy az európai közjog normatív alapstruktúrája mint jogi iránymutatás elvárja, hogy a jogrendszer minden szereplöje, habár nem alkotnak homogén jogi kultúrát, múködjön közös ismeretek, készségek és értékek mentén. A joggyakorlat és a jogelmélet területén a nemzeti értelmezéseket dogmatikai tartalmukkal együtt az európai közjog perspektívájából kell megvizsgálni, de semmiképp nem kell mindig harmonizálásra törekedni, hiszen más jogrendszerek jogi aktusainak és alakzatainak jogtudományi és gyakorlati helyi értékét tekintve nem létezik általános konszenzus. Véleményük szerint az alkotmánybíráskodás összehasonlításának funkcióját három típusba sorolhatjuk: egy kijelentés igazolása, egy bizonyos megállapítást hordozó, fogalmi keret kialakítása és az egymással szembeállítás. Mivel egy pluralisztikus struktúrában a közös felelósséget csak párbeszéd formájában lehet érvényesíteni, létezhet egy összehasonlító értékelés, mint a közös normativitás kibontakoztatásának építóköve (Bogdandy-Grabenwarter-Huber, 2016:18-20). Ez a metodika pedig különösen indokolhatja a nemzetállami alkotmánybíróságok szövetsége rendszerének kiteljesedésével az EU közös szervei és a nemzetállamok jogi konfliktusainak feloldását.

\section{ZÁRÓ GONDOLATOK}

Az intellektuális kihívás mindannyiunk elôtt világossá teszi, hogy szakmai kérdésekben mielóbb jogi döntéseket kell hozni. Ismét Jordan Peterson bölcs gondolataihoz kapcsolódunk. A hogyan továbbra ugyanis a professzor ajánlása nagyon megszívlelendô: „De sohasem lehetünk biztosak abban, hogy mi a legjobb módszer és a legjobb cél. Segít célt választanunk, ha a hagyományra támaszkodunk. Észszerú dolog azt tenni, amit mások eredményesen tettek, hacsak nincs racionális ellenérvünk. S ha igazat mondunk, azzal a leglakhatóbb valóságot hozzuk létre. Az igazság a nemzetek vagyona, biztonsága. Az igazságnak köszönhetôen a múlt valóban múlt marad... Ismerjük fel saját igazságunkat. S azt közöljük értelmesen másokkal! Ez biztosítja a jótékony jövơt, amely a múlt bizonyosságaiban gyökerezik" (Peterson, 2018:255).

\section{FELHASZNÁLT IRODALOM}

Balogh Judit (2007): Közös érdekú ügyek a dualizmus rendszerében. Jogtörténeti Szemle, 9. évf., 3. sz., 2-7. Bogdandy, Armin von - Grabenwarter, Christoph - Huber, Peter M. (Hrsg.) (2016): Handbuch Ius Publicum Europaeum VI. Verfassungsgerichtsbarkeit in Europa: Institutionen. C. F. Müller, Heidelberg.

Braudel, Fernand (2008): A kapitalizmus dinamikája. Európa Könyvkiadó, Budapest.

Coing, Helmut (1996): A jogfilozófia alapjai. Osiris Kiadó, Budapest. 
Eisenmann, Louis (1904): Le compromis Austro-Hongrois de 1867. Étude sur le dualisme. Paris.

Gecsényi Lajos - Máthé Gábor (szerk.) (2009): Sub clausula 1989. Dokumentumok a politikai rendszerváltozás történetéhez. A Grand Strategy. Magyar Közlöny Lap- és Könyvkiadó, Budapest.

Hargitai József (2004): A jog térszerkezetének változásai. Kézirat, Budapest.

Hargitai József (2008): Nemzetközi jog a gyakorlatban. Magyar Közlöny Lap- és Könyvkiadó Vállalat, Budapest.

Harmat Árpád Péter (2015): A bécsi kongresszus és a Szent Szövetség. Történelem Cikkek, http://tortenelemcikkek.hu/node/319.

Jameson, Fredric (2010): A posztmodern, avagy a kései kapitalizmus kulturális logikája. Noran Libro, Budapest. Kádár Béla (2018): Gazdasági mozgásterünk. Kézirat, Budapest.

Király Miklós (2007): Egység és sokféleség. Az Európai Unió jogának hatása a kultúrára. Új Ember Kiadó, Budapest.

Luhmann, Niklas (1981): Gerechtigkeit in den Rechtssystemen der modernen Gesellschaft. In: Luhmann, Niklas (Hrsg.): Ausdifferenzieung des Rechts. Beitrage zur Rechtssoziologie und Rechtstheorie. Suhrkamp, Frankfurt.

Máthé Gábor (2013): Magyary Zoltán tudománytörténeti jelentôsége. Polgári Szemle, 9. évf., 3-6. sz.

Máthé, Gábor (2014): Sovereignty - Constitutional State. Acta Univ. Sapientiae, Legal Studies, Vol. 3, No. 1, 29-40.

Máthé Gábor (2015a): A jogállami intézményrendszer klasszikus korszaka és a kettôs monarchia. Jogtörténeti Szemle, 17. évf., 3. sz., Különszám, 34-39.

Máthé, Gábor (2015b): Der ungarische Rechtsstaat in der Zeit der Doppelmonarchie. In: Máthé, Gábor - Ogris, Werner (Hrsg.): Kroatisch-ungarische öffentlich-rechtliche Verhältnisse zur Zeit der Doppelmonarchie. ELTE Eötvös Kiadó, Budapest.

Máthé, Gábor (2017): Die Entwicklung der Verfassung und des Rechts in Ungarn. Dialóg Campus Kiadó, Budapest.

Ogris, Werner (2010): Der Rechtsstaat - eine Einführung. In: Máthé, Gábor - Ogris, Werner (Hrsg.): Die Habsburgermonarchie auf dem Wege zum Rechtsstat? Magyar Közlöny Lap- és Könyvkiadó, Budapest-Wien.

Peterson, Jordan B. (2018): 12 szabály az élethez. Így kerüld el a káoszt! 21. Század Kiadó, Budapest.

Preuss, Ulrich K. (1999): Krise des regulativen Rechts. Kritische Justiz, Vol. 32, No. 1, 126-131.

Rabkin, Jeremy A. (2004): The Case for Sovereignty. Why the World Should Welcome American Independence. American Enterprise Institute, Washington.

Sári János (1995): A hatalommegosztás. Osiris Kiadó, Budapest.

Strauss, Leo (1999): Természetjog és történelem. Pallas Stúdió - Attraktor Kft., Budapest.

Szentes Tamás (2002): Globalizáció, regionális integrációk és nemzeti fejlődés korunk világgazdaságában. Savaria University Press, Szombathely.

Szúcs Jenô (1983): Vázlat Európa három történeti régiójáról. Magvetô Könyvkiadó, Budapest. 